\title{
Unmet need for modern contraceptive method and associated factors among married women in mekelle city, Tigray, Ethiopia: Community based cross sectional study
}

Desta Hailu ( $\square$ destahailu19@gmail.com )

Senait Tekeste

Mekelle University

Desta Siyoum

Mekelle University

Research

Keywords: Unmet need, married women, Mekelle city, Tigray region, Ethiopia

Posted Date: December 26th, 2019

DOl: https://doi.org/10.21203/rs.2.19539/v1

License: (c) (1) This work is licensed under a Creative Commons Attribution 4.0 International License.

Read Full License 


\section{Abstract}

Background: Contraceptive use has increased markedly in the recent years in most developing countries, due to desire for smaller families; however, millions of women still want to delay or avoid pregnancy but are not using contraception to limit or to space their birth.Thus, the objective of this study is to assess unmet need for family planning among married women in Mekelle city, Tigray.

Methods: Community based cross-sectional study was conducted among married reproductive age women. Data were collected from October, 15 up to Novmber, 15/ 2018. A total of 426 study participants were interviewed using a systematic random sampling technique. Structured and interviewer administered questionnaire was used to collect the data and were analyzed using SPSS version 22. Bivariate and multivariable logistic regression models were used to assess the predictors of the outcome variable. P-value of less than 0.05 was considered to test statistical significance.

Results: The overall unmet need for modern contraception among the currently married women of reproductive age women was $19.7 \%$ (95\% Cl: $16.2 \%-23.7 \%)$ and of which $13.3 \%$ was unmet need for spacing and $6.4 \%$ was unmet need for limiting. Age of mother $(25-34$ years: $A O R=2.79,95 \% \mathrm{Cl}=1.03-$ $7.60)$, occupational status of mother $(A O R=2.72,95 \% \mathrm{Cl}=1.72-4.02)$, number of living children ( $A O R$ $=2.3195 \% \mathrm{Cl}=1.09-4.84)$ and knowledge of mother about modern contraceptive methods (AOR =3.38, $95 \% \mathrm{Cl}=1.82-9.92)$ were independent predicators for unmet need for modern contraception.

Conclusion: The prevalence of unmet need for contraception is low. Age of mother, occupational status of mother, number of children and knowledge of mother about modern contraceptive methods were the independent predicators for unmet need of modern contraception. Strong effort should be made by health care workers to reduce unmet need and policy makers should use different approaches to educate women about modern contraception and increase its utilization for spacing and limiting.

\section{Introduction}

According to world health organization (WHO), unmet need for contraception is the proportion of currently married women or in a sexual union desiring to limit or space childbearing but not using any contraceptive methods. The concept of unmet need points to the gap between women's reproductive intentions and their contraceptive behavior (1).It remains a useful tool for identifying and targeting women at high risk of unintended pregnancy. Unmet need for contraception is one of the several frequently used indicators for monitoring of family planning programs, and it was lastly added to the millennium development goal(MDG) of improving child and maternal health (2). The use of modern contraceptive method remains an important component in the reduction of fertility, maternal, infant and child mortality. This allows couples to fulfill their fertility desires and will improve the health of mothers, children, and the family. The method used to give couples the ability to space child births, the ability of women and their partners to plan their pregnancies and avoid unwanted pregnancy which may lead to unsafe abortions that have negative health consequences for the women $(3,4)$. 
Family planning has many potential benefits. It reduces poverty, maternal and child mortality; empowers women by lightening the burden of excessive childbearing and it reduces environmental degradation by stabilizing the population of the planet. $(5,6)$

Unintended pregnancy related to unmet need is a worldwide problem that affects women and their families and societies at large. About $40 \%$ of all births that occurred globally in 2012 were unwanted posing hardships for families and jeopardizing the health of millions of women and children (7).

"Family Planning; is the Changing Path of Unmet Need" [8]. Unmet need for family planning is defined as percentage of all fecund reproductive age women who are married and in consensual union and presumed to be sexually active but are not using any method of contraception, either do not want to have more children, "Limiter" or want to postpone their next birth for at least two years, "Spacer" [9-11].

In order for modern methods of FP to be used, they need to be available, affordable and acceptable. Interventions that make FP methods more available and affordable are necessary but not sufficient. Use of contraception increased in areas where it was more readily available and not cost prohibitive for a population with few to no discretionary funds. However, efforts to improve rates of contraception uptake in low resourced areas such as sub-Saharan Africa should include factors of acceptability (12)

Results of different literature reviews indicate that many women have only limited access to health centers or FP services. Increasing utilization of FP methods are a safe and affordable intervention that will not only decrease maternal mortality, but also improve maternal morbidity, infant mortality, women's opportunities for education, reduce poverty, and decrease unsafe abortion $(13,14)$.

When human reproduction is left unchecked, it causes high birth rates, getting large family size with the negative effects on the health of mothers and children. Consequently, this leads to negative impact on the family, community and nation at large as a result of economic crisis. Globally, the prevalence of contraceptive use has been increasing, but the unmet need for contraception still remains a problem especially in sub-Saharan Africa. More than 80 million unwanted pregnancies occur each year worldwide leading to high rates of induced abortion, maternal morbidity and mortality, and infant mortality. Women with unmet need for contraception account for over $80 \%$ of unintended pregnancy $(15,16)$

Globally, $12 \%$ of married or in-union women are estimated to have had unmet need for contraceptive methods. The level is much higher, $22 \%$, in the least developed countries. Many of the latter countries are in sub-Saharan Africa, which is also the region where unmet need for contraception method is highest (24\%), double the world average. More than half a million women aged 15-49 years die annually from preventable pregnancy-related complications $(17,18)$.

According to the WHO report, the contraceptive use has increased in many parts of the world, especially in Asia and Latin America, but continues to be low in sub-Saharan Africa. The prevalence of unmet need for contraception in Africa, Asia, and Latin America is $23.2 \%, 10.9 \%$ and $10.4 \%$ respectively. This high 
magnitude of unmet need caused for a rapid population growth and a shortage of services particularly in less developed countries (19).

In Saudi Arabia the prevalence of unmet need was $32.6 \%$. The proportion of spacers and limiters among this group was $65.7 \%$ and $34.4 \%$ respectively (20). In sub-Saharan Africa, $25 \%$ of women of reproductive age who are married or in union have anUnmet need for family planning (21).

In Nigeria the level of unmet need is like the other African countries the unmet need for family planning was $16.1 \% .(22)$

According to the latest national survey, almost one-quarter of young married women in Tanzania reported having an unmet need for family planning, and one-third of sexually active unmarried women reported having an unmet need. (23)

Modern contraceptive use by currently married Ethiopian women has steadily increased over the last 15 years, jumping from $6 \%$ of women using modern contraceptive method in 2000 to $35 \%$ in 2016 . Analysis conducted on demographic health survey shows that unmet need for family planning has decreased over time as contraceptive use has risen. From 2000 to 2011, the unmet need for family planning declined by 10.3 absolute percentage points, from 36.6 percent in 2000 to 26.3 percent in 2011 . The results show that there was 38 percent decline in unmet need for limiting and a 21 percent decline in unmet need for spacing. According to the few surveys conducted on unmet need for FP suggested that unwanted pregnancy and unsafe abortion are main causes of maternal mortality in Ethiopia .According to the 2016 Ethiopian demographic and health survey, the level of unmet need in Ethiopia was $22 \%$ and the level of unmet need for family planning in Tigray is lower than the national level $18 \%(24-26)$ and thisis supported by the single study conducted in shire endasilasie $21.4 \% .(27)$

According to an estimate, 225 million women in developing countries had an unmet need for contraception. Annually, an estimated 74 million unintended pregnancies occur in developing regions, most of them are women using no contraception or a traditional method. If all unmet need for modern methods were met, 70,000 deaths from pregnancy related causes could be prevented (28).

Even if the level of contraceptive prevalence rate was increased from time to time large number of currently married women was still found with high number of unmet need for modern family planning. To the best of my knowledge little is known about the level of unmet need among currently married women of Mekelle city. That's why this study aims to assess the level of unmet need among currently married women of Mekelle city, Tigray region, northern Ethiopia

\section{Methods And Materials}

\subsection{Study Area and period}


The study was conducted in Mekelle city. Mekelle is found in the northern part of Ethiopia which is 783 kilometers away from Addis Ababa, the country's capital. Mekelle is a capital city of the national state of Tigray. The population of Mekelle city is estimated to be 396,570 , of these 191,664 are women. Mekelle is found 2000-2200 meters above sea level and it has $618 \mathrm{~mm}$ of annual rainfall. The weather condition of Mekelle city is weinadega; on average it has $17.6^{\circ} \mathrm{C}$ temperatures (37). The study was conducted from October, 15 up to Novmber, 15/ 2018.

\subsection{Study design and population}

Community based cross-sectional study was employed among randomely selected participants. Married/in union and sexually active women who live in Mekelle were included. Where as, reproductive age women (15-49 years) who were critically ill and having hearing or mental health problems during data collection period were excluded from the study.

\subsection{Sample size determination and sampling procedure}

Sample size was calculated using the single population proportion formula based on the following assumptions, $95 \%$ confidence interval with a $5 \%$ margin of error, the expected proportion of prevalence unmet need for family planning from previously conducted study in Shire Endaselassie (P) is $21.4 \%$ (27).

Formula $(\mathrm{N})==1.96$ at $\mathrm{Cl}$ of $95 \%$

$(N)=(1.96)^{2}(0.786 \times 0.214) /(0.05) N=258.47=259$

Adding $10 \%(25.85=26)$ non-response rate, sample size became $284.32=285$; and since the sampling method was multistage, design effect of 1.5 was taken and then, final sample size became $(n)=426.48=$ 426.

Multistage sampling method was used as a sampling procedure. Under Mekelle city there were seven sub cities. Three sub cities including Ayder, kedamay weyane and Adi haqi subcities were randomely selected.The number of ketenas to be studied in each sub cities was obtained from each sub cities administration. The ketenas were similarly selected randomly using lottery method and four ketenas were selected from each sub cities. The ketenas' arrangement and references list information were obtained from respective urban health extension workers (UHEWs). Based on the number of married reproductive age group women in each ketena, a total sample size of 426 were proportionally allocated to each ketena depending on their total number of currently married reproductive age group women. To select the study units from each ketena, systematic random sampling method was used to determine the women to be interviewed. Every $\mathrm{K}^{\text {th }}$ interval participant was enrolled to the study and randomly generated numbers were used to select the first study unit.

\subsection{Data collection tools and techniques}


Data were collected using structured interview administered questionnaire and prepared in English and was translated into Tigrigna and then translated back to English language by language experts to check for its consistency and clarity. Questionnaires were adapted and modified from Ethiopian Demographic and Health Survey (EDHS) 2016, for contraceptive methods and other literature reviews $(38,39)$.

Information about Sociodemographic, economic, reproductive history, contraceptive and service provider was gathered. The questionnaire was pretested in $5 \%$ of the total sample size who live in non-selected ketenas, of Mekelle ciy.

Data were collected through house to house visiting in the sub cities by interviewing the respondents with the trained data collectors after informed consent was obtained. Data were collected by 4 trained diploma nurses and supervised by 2 BSc nurses to check the overall data collection process. The filled questionnaires were checked daily by the supervisors and principal investigator. During data collection, if there were more than two eligible women in households, one woman was selected randomly. The principal investigator was also checking for completeness, errors and ambiguities on daily basis.

\subsection{Operational definitions}

Unmet need of contraception:refers to the contraceptive need of fecund and currently married women or living in union who are either not pregnant and want child latter on or not at all, or who are pregnant as result of a mistimed or unwanted pregnancy but not using any contraceptive method (19). Unmet need for spacing: - the percentages of not pregnant women who want another child after two years and who are pregnant as result of a mistimed pregnancy but not using modern any modern contraceptive methods. Unmet need for limiting: - the percentages of not pregnant women who do not want another child at all and who were pregnant as a result of unwanted pregnancy but not using any modern contraceptive methods.

Favorable attitude towards methods-: those respondents who scored points greater than or equal the attitude mean score (45.2) of the total 12 items of attitude related questionswith 1 to 5 pointsLikert scale. Unfavorable attitude towards methods-: those respondents who scored points less than the attitude mean score (45.2) of the total 12 items of attitude related questionswith 1 to 5 points Likert scale. (33).

- Data processing, management and Quality Assurance

- After appropriate coding, the data were entered using Epi Info version 3.5.3 software and exported to SPSS version 20 software for analysis. Univariate analysis was computed for each independent variable to assess their individual proportion. Then, bivariate analysis was executed to examine crude association of predictors with short inter birth intervals. Finally, variables which had $p$-value less than or equal to 0.4 on bivariate analysis were selected as candidates for multivariable analysis. In multivariable logistic regression analysis, the independent effect of predictors on short inter birth interval were examined. Backward step wise LR was used to identify variables which had the largest contribution to the model. Odds ratio and $95 \% \mathrm{Cl}$ were used to measure the statistical association. $\mathrm{P}$ 
value 0.05 was used to determine the statistical significance of the tests. Finally, the results were presented in texts, tables and graphs.

To assure the quality of the data, training was given to the data collectors and supervisors by the principal investigator for two days on instruction for the methods, how to take informed consent, how to approach participants, ethical procedure and general information on unmet need of contraception and the objective of the study. The questionnaire was prepared in English and translated in to Tigrigna then back to English by different persons to check its consistency. Data quality was assured through pre-test of the questionnaire among $5 \%(n=22)$ of the participants living out side trhe study area. Filled out questionnaires were checked for completeness and errors in entries daily by supervisors and principal investigator and necessary corrections were made on the spot.

Ethical considerations

- After approval, ethical clearance was obtained from institutional Review Board (IRB) of College of Health sciences, Mekelle University. Then, official letter was written from Mekelle University, College of Health sciences to Tigray health office. Permission letters from district health office were processed before starting data collection. At the beginning of the data collection, written informed consent was obtained from each respondent after through explanation of the purpose and the procedures of the study. Mothers were also informed that all the data obtained from them would be kept confidential and anonymous. To ensure confidentiality, names of respondents were replaced by code numbers.

\section{Results}

\subsection{Socio-demographic characteristics of study participants}

In this study, a total of 426 currently married women were included which makes a response rate of $100 \%$. The mean age $( \pm S D)$ of the respondents was $28.4 \pm 7.0$ years old. More than half, $245(57.5 \%)$ of the respondents' were Orthodox followed by Muslim, 87(20.4\%) and about 78 (18.3\%) of the respondents were illiterate. Of the total respondents, 271 (63.6\%) of them were Tegaru in ethnicity and around 219 $(51.4 \%)$ of the household's monthly income were in the range of 1001-2000 Ethiopian Birr (Table 1). 
Table 1

Socio-demographic characteristics of study participants in Mekelle City, Tigray region, Northern Ethiopia, 2018/9 ( $n=426)$

\begin{tabular}{|c|c|c|c|}
\hline Variables & Variable category & $\mathrm{n}$ & $\%$ \\
\hline \multirow[t]{7}{*}{ Age in years } & $15-19$ & 41 & 9.6 \\
\hline & $20-24$ & 90 & 21.1 \\
\hline & $25-29$ & 127 & 29.8 \\
\hline & $30-34$ & 86 & 20.2 \\
\hline & $35-39$ & 44 & 10.3 \\
\hline & $40-44$ & 26 & 6.1 \\
\hline & $45-49$ & 12 & 2.8 \\
\hline \multirow[t]{4}{*}{ Religion } & Orthodox & 245 & 57.5 \\
\hline & Muslim & 87 & 20.4 \\
\hline & Protestant & 38 & 8.9 \\
\hline & Catholic & 56 & 13.1 \\
\hline \multirow[t]{3}{*}{ Ethnicity } & Tigray & 271 & 63.6 \\
\hline & Amhara & 83 & 19.5 \\
\hline & Others* & 72 & 16.9 \\
\hline \multirow[t]{4}{*}{ Educational status } & Illiterate & 78 & 18.3 \\
\hline & Elementary school (1_8th) & 226 & 53.1 \\
\hline & High school (9th _ 12th ) & 99 & 23.2 \\
\hline & Higher education (Diploma and above) & 23 & 5.4 \\
\hline \multirow[t]{4}{*}{ Partner's education } & Illiterate & 92 & 21.6 \\
\hline & Elementary school (1_8th) & 158 & 37.1 \\
\hline & High school (9th _ 12th ) & 143 & 33.6 \\
\hline & Higher education (Diploma and above) & 33 & 7.7 \\
\hline \multirow[t]{3}{*}{ Occupational status } & Housewife & 293 & 68.8 \\
\hline & Merchant & 85 & 20.0 \\
\hline & Student & 20 & 4.7 \\
\hline
\end{tabular}




\begin{tabular}{|c|c|c|c|}
\hline Variables & Variable category & $\mathbf{n}$ & $\%$ \\
\hline & Daily laborer & 24 & 5.6 \\
\hline & Others & 4 & 0.9 \\
\hline \multirow[t]{5}{*}{ Partner's occupation } & Jobless & 100 & 23.5 \\
\hline & Gov't employed & 214 & 50.2 \\
\hline & Merchant & 64 & 15.0 \\
\hline & Student & 10 & 2.3 \\
\hline & Others** & 38 & 8.9 \\
\hline \multirow[t]{4}{*}{ Family monthly income (ETB) } & $<1000$ & 31 & 7.3 \\
\hline & $1001-2000$ & 219 & 51.4 \\
\hline & $2001-3000$ & 176 & 41.3 \\
\hline & $>3000$ & 31 & 7.3 \\
\hline
\end{tabular}

\subsection{Reproductive characteristics of study participants}

From the total respondents, around two third,287(67.4\%) of them got married in the age range of 1824 years old. Most, 369 (86.6\%), of the respondents had pregnancy history and 320 (86.7\%) had ever gave birth. Moreover, $85(23.0 \%)$ of the respondents were currently pregnant of which, $65(76.5 \%)$ of them were wanted. Moreover, $159(43.1 \%)$ of respondents had more than five currently living children (Table 2). 
Table 2

Reproductive characteristics of study participants in Mekelle City, Tigray region, Northern Ethiopia, 2018/9 ( $n=426)$

\begin{tabular}{|c|c|c|c|}
\hline Variables & Variable categories & $\mathbf{N}$ & $\%$ \\
\hline \multirow[t]{3}{*}{ Age at first marriage (in years) } & $<18$ & 121 & 28.4 \\
\hline & $18-24$ & 287 & 67.4 \\
\hline & $>25$ & 18 & 4.2 \\
\hline \multirow[t]{2}{*}{ History of pregnancy } & Yes & 369 & 86.6 \\
\hline & No & 57 & 13.4 \\
\hline \multirow[t]{2}{*}{ History of delivery $(n=369)$} & Yes & 320 & 86.7 \\
\hline & No & 49 & 13.3 \\
\hline \multirow[t]{3}{*}{ Number of pregnancies $(n=369)$} & $1-2$ & 87 & 23.6 \\
\hline & $3-4$ & 159 & 43.1 \\
\hline & $\geq 5$ & 123 & 33.3 \\
\hline \multirow[t]{2}{*}{ History of abortion $(n=369)$} & Yes & 55 & 14.9 \\
\hline & No & 314 & 85.1 \\
\hline \multirow[t]{2}{*}{ Number of experienced abortion $(n=55)$} & 1 time & 46 & 83.6 \\
\hline & $\geq 2$ times & 9 & 16.4 \\
\hline \multirow[t]{2}{*}{ Number of living children } & $<5$ & 210 & 56.9 \\
\hline & $\geq 5$ & 159 & 43.1 \\
\hline \multirow[t]{2}{*}{ Are you currently pregnant $(n=200)$} & Yes & 85 & 23.0 \\
\hline & No & 115 & 77.0 \\
\hline \multirow[t]{3}{*}{ Status of pregnancy $(n=85)$} & Wanted now & 65 & 76.5 \\
\hline & Unwanted & 16 & 18.8 \\
\hline & Mistimed & 4 & 4.7 \\
\hline \multirow[t]{4}{*}{ Reasons for not being pregnant $(n=115)$} & Want later on after two years & 53 & 46.1 \\
\hline & No more child needed & 11 & 9.6 \\
\hline & Want soon with in two years & 31 & 26.9 \\
\hline & Infecund & 20 & 17.4 \\
\hline
\end{tabular}




\begin{tabular}{|llll|}
\hline Variables & Variable categories & N & $\%$ \\
\hline & Unsure when want to have & 0 & 0.0 \\
\hline
\end{tabular}

\subsection{Modern contraceptive method utilization status}

Out of 426 married women interviewed, $305(71.6 \%)$ of them were ever used some methods of contraception in their life time while $226(53.1 \%)$ currently used modern contraceptive methods during the time of the interview of which, 187(82.7\%) were for spacing and 39(17.3) for limiting birth. The main reasons for not to using modern contraceptive methods were, fear of side effects, $102(65.0 \%)$, want to have more children, 84(52.9\%) and other health concerns 79(50.1\%) (Table 3). 
Table 3

Modern contraceprive productive related characteristics of study participants in Mekelle City, Tigray region, Northern Ethiopia, 2018/9 $(n=426)$

\begin{tabular}{|c|c|c|c|}
\hline Variables & Variable categories & $\mathbf{N}$ & $\%$ \\
\hline \multirow[t]{2}{*}{ Ever use of modern contraceptive methods } & Yes & 305 & 71.6 \\
\hline & No & 121 & 28.4 \\
\hline \multirow[t]{2}{*}{ Current use of modern contraceptive methods } & Yes & 226 & 53.1 \\
\hline & No & 200 & 46.9 \\
\hline \multirow[t]{6}{*}{ Type contraceptive methods used $(n=226)^{*}$} & Oral pill & 23 & 28.0 \\
\hline & Injectable & 34 & 41.5 \\
\hline & Implant & 15 & 18.3 \\
\hline & IUCD & 4 & 4.9 \\
\hline & Condom & 3 & 3.7 \\
\hline & Permanent & 3 & 3.7 \\
\hline \multirow{2}{*}{$\begin{array}{l}\text { Reasons for use of modern contraceptive } \\
\text { methods }(n=226)\end{array}$} & Spacing birth & 187 & 82.7 \\
\hline & Limiting birth & 39 & 17.3 \\
\hline \multirow{12}{*}{$\begin{array}{l}\text { Reasons for not using contraceptive methods } \\
(n=200)^{\star}\end{array}$} & Husband is not present now & 59 & 8.1 \\
\hline & Want to have more children & 84 & 11.5 \\
\hline & $\begin{array}{l}\text { Difficulty of getting } \\
\text { pregnant/infertility }\end{array}$ & 20 & 2.7 \\
\hline & Breast feeding & 38 & 5.2 \\
\hline & Respondent opposition & 64 & 8.8 \\
\hline & Husband opposition & 78 & 10.8 \\
\hline & Religious opposition & 38 & 5.2 \\
\hline & Lack of knowledge about methods & 54 & 7.4 \\
\hline & $\begin{array}{l}\text { Lack of information about source of } \\
\text { methods }\end{array}$ & 37 & 5.1 \\
\hline & health concerns & 79 & 10.9 \\
\hline & fear of side effects & 102 & 14.0 \\
\hline & other reason & 75 & 10.3 \\
\hline
\end{tabular}




\subsection{Knowledge and attitude towards to contraceptive methods}

A total of $342(80.3 \%)$ of respondents ever heard about modern contraceptive methods and the most frequently mentioned source of information of them were health professionals, 259 (73.0\%) followed by CHWs, 225 (63.4\%).Regarding to the over all knowledge and favorable attitude towards modern contraceptive among women was,259(60.8\%) and 135(31.7\%), respectively (Table 4). 
Table 4

Knowledge and attitude to modern contraceptives methods of study participants in Mekelle City, Tigray region, Northern Ethiopia, 2018/9 $(n=426)$

\begin{tabular}{|c|c|c|c|}
\hline Variables & Categories & $\mathbf{N}$ & $\%$ \\
\hline \multirow[t]{2}{*}{ Ever heard of modern contraceptive methods } & Yes & 342 & 80.3 \\
\hline & No & 84 & 19.7 \\
\hline \multirow[t]{9}{*}{ Type of modern contraceptive method you know* } & Oral pills & 290 & 90.3 \\
\hline & emergency contraception & 104 & 32.4 \\
\hline & Injectable & 282 & 87.9 \\
\hline & Female Condom & 277 & 86.3 \\
\hline & Male condom & 83 & 25.9 \\
\hline & Implant & 201 & 62.6 \\
\hline & Intrauterine device (IUCD) & 153 & 47.7 \\
\hline & Male sterilization & 61 & 19.0 \\
\hline & Female sterilization & 84 & 26.2 \\
\hline \multirow[t]{8}{*}{$\begin{array}{l}\text { Source of information for modern contraceptive } \\
\text { methods* }\end{array}$} & $\begin{array}{l}\text { Health professional (Dr \& } \\
\text { nurse) }\end{array}$ & 259 & 73.0 \\
\hline & Health institutions & 202 & 58.6 \\
\hline & CHWs & 225 & 63.4 \\
\hline & Friends & 139 & 39.2 \\
\hline & Radio & 170 & 47.9 \\
\hline & Television & 85 & 23.9 \\
\hline & Newspaper & 158 & 44.5 \\
\hline & Husband & 270 & 76.1 \\
\hline \multirow{4}{*}{$\begin{array}{l}\text { Main places to get modern } \\
\text { contraceptive methods* }\end{array}$} & Health institutions & 202 & 82.8 \\
\hline & Pharmacy & 134 & 54.9 \\
\hline & Reproductive health clinic & 118 & 48.4 \\
\hline & Others & 78 & 32.0 \\
\hline Advantages of modern contraceptive methods* & $\begin{array}{l}\text { To avoid unwanted } \\
\text { pregnancy }\end{array}$ & 325 & 92.3 \\
\hline
\end{tabular}




\begin{tabular}{|llll|}
\hline Variables & Categories & N & \% \\
\hline & To space for family size & 218 & 61.9 \\
\cline { 2 - 4 } & To regulate period & 120 & 34.1 \\
\cline { 2 - 4 } Knowledge about modern contraceptive methods & To prevent STD/HIV & 228 & 64.8 \\
& Yes & 259 & 60.8 \\
\cline { 2 - 4 } Mothers attitude & No & 167 & 39.2 \\
towards contraceptive & Favorable attitude & 135 & 31.7 \\
\cline { 2 - 4 } & Unfavorable attitude & 291 & 68.3 \\
\hline Exposure to media(Radio, TV) & Yes & 201 & 47.2 \\
\cline { 2 - 4 } & No & 225 & 52.8 \\
\cline { 2 - 4 }
\end{tabular}

\subsection{Partners and health service related charactersitics}

A total of $275(64.6 \%)$ of respondents ever discussed about modern contraceptive methods with their partners and almost half, 208 (48.8\%) get partners support to use contraceptive methods preceeding the survey.Similarly, $244(57.3 \%)$ of the respondnets discussed with health professionals about contraceptive methods (Table 5). 
Table 5

Partner and health service related charactersitics of study participants in Mekelle City, Tigray region, Northern Ethiopia, $2016(n=426)$

\begin{tabular}{|c|c|c|c|}
\hline Variables & Categories & $\mathbf{N}$ & $\%$ \\
\hline \multirow{2}{*}{$\begin{array}{l}\text { Ever discussed about contraceptive methods with } \\
\text { your partner }\end{array}$} & Yes & 275 & 64.6 \\
\hline & No & 151 & 35.4 \\
\hline \multirow[t]{2}{*}{ Partner support to use contraceptive methods } & Yes & 208 & 48.8 \\
\hline & No & 218 & 51.2 \\
\hline \multirow[t]{3}{*}{ Decision on number of children to have } & My decision & 50 & 11.7 \\
\hline & My partner & 53 & 12.4 \\
\hline & Both of us & 323 & 75.8 \\
\hline \multirow[t]{2}{*}{ Availability of modern contraceptive methods } & Yes & 140 & 61.9 \\
\hline & No & 86 & 38.1 \\
\hline \multirow[t]{2}{*}{ Convenient site of modern contraceptive services } & Yes & 198 & 87.6 \\
\hline & No & 28 & 12.4 \\
\hline \multirow[t]{4}{*}{ Reasons for not convenient site* } & Providers Ignorance & 57 & 82.6 \\
\hline & Lack of privacy & 52 & 75.4 \\
\hline & $\begin{array}{l}\text { Difficult to obtain health } \\
\text { professionals }\end{array}$ & 33 & 47.8 \\
\hline & $\begin{array}{l}\text { Fearful for health professionals } \\
\text { to be discuss }\end{array}$ & 60 & 87.0 \\
\hline \multirow{2}{*}{$\begin{array}{l}\text { Ever discussed about contraceptive methods with } \\
\text { health professional }\end{array}$} & Yes & 244 & 57.3 \\
\hline & No & 182 & 42.7 \\
\hline \multirow{2}{*}{$\begin{array}{l}\text { Ever discussed about contraceptive methods with } \\
\text { CHWs }\end{array}$} & Yes & 266 & 62.4 \\
\hline & No & 160 & 37.6 \\
\hline \multirow{2}{*}{$\begin{array}{l}\text { Ever visited health facility for modern } \\
\text { contraceptive methods? }\end{array}$} & Yes & 218 & 51.2 \\
\hline & No & 208 & 48.8 \\
\hline
\end{tabular}

\subsection{Prevalence of unmet need among women}

The overall unmet need for modern contraceptive methods among currently married women was found to be $84(19.7 \%)$ of which, $57(13.3 \%)$ for spacing and $27(6.4 \%)$ for limiting (Fig. 2). 
Figure 2. Total unmet need for modern contraceptive methods of study participants in Mekelle City, Tigray region, Northern Ethiopia, $2016(n=426)$

\subsection{Factors associated with unmet need of modern contraceptive methods}

Among the variables entered into bivariate logistic regression analysis, age of mother, educational status of mother, partner's educational status, occupational status of mother, age at first marriage, ever gave birth a child, number of living children, history of abortion, reasons for use of modern contraceptive methods, knowledge of mother about modern contraceptive methods, attitude of mother towards modern contraceptive methods, ever discussed about modern contraceptive methods with partner and decision maker on number of children to have were found to be significantly associated (at p-value $<0.25$ ) and were candidate variables for the final multivariable logistic regression model analysis (Table 6). 
Table 6

Factors associated with unmet need of modern contraception among study participants in Mekelle City, Tigray region, Northern Ethiopia, 2018/9 $(n=426)$

\begin{tabular}{|c|c|c|c|c|c|}
\hline \multirow[t]{2}{*}{ Variables } & \multirow[t]{2}{*}{ Category } & \multicolumn{2}{|c|}{$\begin{array}{l}\text { Unmet need for } \\
\text { modern contraception } \\
(n=426)\end{array}$} & \multirow[t]{2}{*}{$\begin{array}{l}\text { COR 95\% } \\
\mathrm{Cl}\end{array}$} & \multirow[t]{2}{*}{$\begin{array}{l}\text { AOR 95\% } \\
\mathrm{Cl}\end{array}$} \\
\hline & & Yes (84) & No(342) & & \\
\hline \multirow[t]{3}{*}{ Age in years } & $15-24$ & $9(6.9)$ & 122(93.1) & 1 & 1 \\
\hline & $25-34$ & $52(24.4)$ & $161(75.6)$ & $\begin{array}{l}4.38(2.08- \\
9.23)\end{array}$ & $\begin{array}{l}2.79(1.03- \\
7.60)^{\star}\end{array}$ \\
\hline & $35-49$ & $23(28.0)$ & $59(72.0)$ & $\begin{array}{l}5.28(2.30- \\
12.13)\end{array}$ & $\begin{array}{l}3.94(1.17- \\
13.19)^{\star}\end{array}$ \\
\hline \multirow[t]{2}{*}{ Educational status } & Illiterate & $25(32.1)$ & $53(67.9)$ & $\begin{array}{l}2.31(1.33- \\
4.01)\end{array}$ & $\begin{array}{l}0.87(0.36- \\
2.19)\end{array}$ \\
\hline & Educated & $59(17.0)$ & 289(83.0) & 1 & 1 \\
\hline \multirow[t]{2}{*}{ Partner's education } & Illiterate & $23(25.0)$ & $69(75.0)$ & $\begin{array}{l}1.49(0.86- \\
2.57)\end{array}$ & $\begin{array}{l}0.48(0.19- \\
1.23)\end{array}$ \\
\hline & Educated & 61(18.3) & 273(81.7) & 1 & \\
\hline \multirow[t]{2}{*}{ Occupational status } & Housewife & $71(24.2)$ & $222(75.8)$ & $\begin{array}{l}2.95(1.57- \\
2.55)\end{array}$ & $\begin{array}{l}2.72(1.73- \\
4.02)^{\star}\end{array}$ \\
\hline & Working & $13(9.8)$ & $120(90.2)$ & 1 & 1 \\
\hline \multirow[t]{2}{*}{ Age at first marriage } & $<18$ years & 16(13.2) & $105(86.8)$ & 1 & 1 \\
\hline & $\geq 18$ years & $68(22.3)$ & 237(77.7) & $\begin{array}{l}1.88(1.04- \\
3.40)\end{array}$ & $\begin{array}{l}0.81(0.37- \\
1.79)\end{array}$ \\
\hline \multirow[t]{2}{*}{ Ever given birth a child } & Yes & $76(23.8)$ & $244(76.3)$ & $\begin{array}{l}1.87(0.81- \\
4.33)\end{array}$ & $\begin{array}{l}0.75(0.25- \\
2.26)\end{array}$ \\
\hline & No & $7(14.3)$ & $42(85.7)$ & 1 & 1 \\
\hline \multirow[t]{2}{*}{ Number of living children } & $\geq 5$ & $50(31.4)$ & $109(68.6)$ & $\begin{array}{l}2.46(1.49- \\
4.06)\end{array}$ & $\begin{array}{l}2.31(1.09- \\
4.84)^{\star}\end{array}$ \\
\hline & $<5$ & $33(15.7)$ & $177(84.3)$ & 1 & 1 \\
\hline \multirow[t]{2}{*}{ History of abortion } & Yes & $16(29.1)$ & $39(70.9)$ & $\begin{array}{l}1.51(0.79- \\
2.87)\end{array}$ & $\begin{array}{l}2.46(0.99- \\
6.12)\end{array}$ \\
\hline & No & $67(21.3)$ & 247(78.7) & 1 & 1 \\
\hline \multirow[t]{2}{*}{$\begin{array}{l}\text { Reasons for use of modern } \\
\text { contraceptive methods }\end{array}$} & Spacing & $42(22.5)$ & $145(77.5)$ & $\begin{array}{l}0.52(0.25- \\
1.08)\end{array}$ & $\begin{array}{l}0.48(0.21- \\
1.14)\end{array}$ \\
\hline & Limiting & $14(35.9)$ & $25(64.1)$ & 1 & 1 \\
\hline
\end{tabular}




\begin{tabular}{|llllll|}
$\begin{array}{l}\text { Knowledge about modern } \\
\text { contraceptive methods }\end{array}$ & Yes & $67(25.9)$ & $192(74.1)$ & $\begin{array}{l}3.08(1.74- \\
5.46)\end{array}$ & $\begin{array}{l}3.38(1.82- \\
9.92)^{*}\end{array}$ \\
\cline { 2 - 6 } & No & $17(10.2)$ & $150(89.8)$ & 1 & 1 \\
\hline $\begin{array}{l}\text { Attitude towards modern } \\
\text { contraceptive methods }\end{array}$ & Favorable & $33(24.4)$ & $102(75.6)$ & $\begin{array}{l}1.52(0.93- \\
2.49)\end{array}$ & $\begin{array}{l}1.67(0.73- \\
3.15)\end{array}$ \\
\cline { 2 - 6 } & Unfavorable & $51(17.5)$ & $240(82.5)$ & 1 & 1 \\
\hline $\begin{array}{l}\text { Ever discussed about modern } \\
\text { contraceptive methods with } \\
\text { partner }\end{array}$ & Yes & $72(26.2)$ & $203(73.8)$ & $4.12(2.15-$ & $1.02(0.39-$ \\
& No & $12(7.9)$ & $139(92.1)$ & 1 & 1 \\
\hline $\begin{array}{l}\text { Decision on number of } \\
\text { children have }\end{array}$ & My decision & $7(14.0)$ & $43(86.0)$ & 1 & 1 \\
\cline { 2 - 6 } & My partner & $5(9.4)$ & $48(90.6)$ & $0.64(0.19-$ & $0.58(0.21-$ \\
& & & & $2.67)$ & $1.43)$ \\
\hline & Both & $72(22.3)$ & $251(77.7)$ & $1.76(0.96-$ & $0.98(0.71-$ \\
& & & & $4.09)$ & $3.56)$ \\
\hline
\end{tabular}

After controlling the effect of probable confounders, final multivariable logistic regression analysis revealed that age of mother $(25-34$ years: $A O R=2.79,95 \% \mathrm{Cl}=1.03-7.60$ and $35-49: \mathrm{AOR}=3.94,95 \% \mathrm{Cl}$ $=1.17-13.19)$, occupational status of mother $(A O R=2.72,95 \% \mathrm{Cl}=1.72-4.02)$, number of living children, $(\mathrm{AOR}=2.3195 \% \mathrm{Cl}=1.09-4.84)$ and knowledge of mother about modern contraceptive methods (AOR = $3.38,95 \% \mathrm{Cl}=1.82-9.92)$ were the independent predicators for unmet need of modern contraception among the study participants.

Therefore, married women who were in the age groups of $25-34$ and $35-49$ were about 2.8 and 3.9 times, respectively, more likely to have unmet need as compared to women in the age group of 1524 years old. Women who were housewife were 2.7 times more likely to have unmet need than working women. Women who have greater than five living children were 2.3 more likely to face unmet need for contraception over those who had fewer than five children. Women who had knowledge on modern contraception were 3.4 times more likely to have unmet need than women who did knew modern contraception.

\section{Discussion}

Contraceptive use has increased markedly in the recent years in most developing countries, due to desire for smaller families; however, millions of women still want to delay or avoid pregnancy but are not using contraception to limit or to spacing their birth (29). Therefore, this community based cross-sectional study was designed to assess prevalence of unmet need for modern contraception and associated factors among currently married women of reproductive age in Mekelle city, Tigray, Northern Ethiopia.

This study revealed that, overall unmet need for modern contraception among currently married women of reproductive age were $19.7 \%$ (95\% Cl: $16.2 \%-23.7 \%$ ) and of which $13.3 \%$ were unmet need for spacing and $6.4 \%$ were unmet needs for limiting. The present findings were similar with the regional $(18.0 \%)$ and 
national (22.3\%) figure of EDHS 2016 report (24), 22.0\% (24 ), Shire Endasilasie, Ethiopia 21.4\% (27), Awi zone, Ethiopia, 17.4\% (11) and Nigeria,16.1\% \% (22), Cameroon,20.4\% (31); but much higher than the findings of various studies conducted in Egypt, 12.7\% [30] and Botswana,9.6\% (32). The possible reason for the difference may be due to study area, design and time of the study. However, it is also lower than the studies done in Misha district, Ethiopia, 26.5\% (34), Bahir Dar City, Ethiopia, 24.3\% (40) and Rural India, $42.0 \%$ (41). The possible explanation of large variation may be due to expansion of health facilities and improved access of health services in the study area. It may also be because of differences in study setting, study population, time of the study, awareness of people on contraceptives and other related socioeconomic characteristics among the study participants.

In the current study, age of the mother was a factor associated with increased unmet need for modern contraception. The married women who were in the age groups of 25-34 and 35-49 were about 2.8 and 3.9 times, more likely to have unmet need as compared to women in the age group of 15-24 years old respectively. The possible explanation could be as age of women increased, there might have better experience sharing and social interaction \& this can improve the awareness on family planning so that level of unmet need also increased in the higher age groups. The other possible explanation may be also due to the fact that women who may face high labour experience and pregnancy related problems as age increases. This finding is similar to studies done in Shire Endasilasie, Ethiopia (27), Bahir Dar City, Ethiopia, (40), India (44).

Another most important factor significantly associated with increased unmet need for modern contraception among the women was occupational status of mother. Women who were housewives were 2.7 times more likely to have unmet need than working women. The possible reason for this might be employed women were more likely to have better access for information about contraception than nonemployed. The result of this studywas similar with other studies conducted in Awi zone, Ethiopia (11), Nagpur, Maharashtra (43), Haryana, India (46).

The current study also revealed an association between women's knowing about family planning and unmet need to modern contraception. Women who had knowledge on modern contraception were 3.4 times less likely to have unmet need than women who did knew modern contraception. This may reflect having awareness or knowledge about modern contraceptives can improve on having better access to information and utilization for modern contraceptives and this leads to increased demand for family planning. There result of this study is in line with other studies conducted in Misha District, Ethiopia, (34), Enemy District, Ethiopia (50) and Lahore, Pakistan (45) and Gumi District, Nepal (49).

Number of living children was also found to be a predictor for unmet need to modern contraceptive methods. Woman who had five or more currently living children were 2.3 times more likely to have unmet need for modern contraceptive than those who has less than five children. The possible explanation could be the likelihood of wanting no more children increases with the actual number of living children. It was consistent with other studies done in Sibu Sire District and North Shoa Zone, Ethiopia $(47,48)$ which indicated that couples who have more children are more likely to have unmet need than the ones who 
have fewer children or none at all.When interpreting the findning of this study, the following limitations should be considered:

First, men were not included as participants to understand their perception towards the unmet need for modern contraception. Second, the study involved a single cross-sectionaldesign. Hence since temporal relation ship of exposure and outcome variables is not known, it is difficult to establish cause -effect relationship. Third, there might be the possibility of recall and reporting bias in some questions which might be loss of information and responded carelessly.

\section{Conclusions And Recommendations}

The present study revealed that the overall unmet need for modern contraception among the currently married women of reproductive age was low during the survey. According to analysis of independent variables with the outcome variables, age of mother, occupational status of mother, number of living children and knowledge of mother about modern contraceptive methods were the independent predicators for unmet need of modern contraception.

Even if unmet need is lower than the national level, health care workers should make a strong effort to reduce the unmet need. Policy makers should also use different approaches to educate reproductive age women targeting house wives, older age women, women with poor knowledge of family planning and those having more than four children so that family planning utilization for spacing and limiting will increase. Finally, conducting large scale study using lobust designs is recommended to be carried out.

\section{Abbreviations}

HSDP:Health sector development plan; EDHS:Ethiopian Demographic and Health Survey; STI:Sexual transmitted infections; FP:family planning; CPR:contraceptive prevalence rate

\section{Declarations}

\section{Ethics approval and consent to participate}

After approval, ethical clearance was obtained from institutional Review Board of Arba Minch University. Then, letter was written to the concerned bodies and permission was secured at all levels. No personal identifiers were declared .lindividual level patient consent is not secured as it was deemed unnecessary

\section{Consent for publication}

Not applicable.

\section{Availability of data and materials}

All the data are presented in the manuscript. Raw data can be obtained from the principal author through email. 


\section{Competing interests}

The authors declare that they have no competing interests.

\section{Funding}

Funding for the study was secured from Mekelle University

\section{Authors' contributions}

ST, DH \& DS conceived the study, participated in data collection, performed analysis and interpretation of the data and drafted the paper and prepared all versions of the manuscript. All authors read and approved the final manuscript.

\section{Acknowledgements}

We are grateful to Mekelle University, College of Health Sciences for sponsoring this research project. We would also like to extend our gratitude to all participants for being volunter to participate. Last but not least, we are grateful to the data collectors for undertaking their tasks with extreme caution.

\section{References}

1. WHO, Unmet need for family planning: Human reproduction program (hrp), 2016.

2. Mills, S., E. Boss, and E. Suzuki, Unmet need for contraception. Public Health at a Glance. 2010.

3. et al., Current contraceptive use and variation by selected characteristics among women aged 15-44: United States, 2011-2013. Natl Health Stat Report, 2015. 86: p. 1-14.

4. a. Chibuye, Family structure and modern contraceptive use among women in Malawi, 2016.

5. Kavanaugh ML, Anderson RM. Contraception and Beyond: The Health Benefits of Services Provided at Family Planning Centers. New York: Guttmacher Institute; 2013. Available at http://www.guttmacher.org/pubs/ health-benefits.pdf. Date accessed May 122018.

6. Family planning. Fact sheet $\mathrm{N}^{\circ} 351$. Updated May 2013. Available at http://www.who.int/mediacentre/factsheets/fs351/en/. Date accessed May 14, 2018

7. Sedgh G, Singh S, Hussain R. Intended and Unintended Pregnancies Worldwide in 2012 and Recent Trends. Stud Fam Plann. 2014;45(3):301-14.

8. Bureau PR. Family Planning: The Changing Path of Unmet Need. Aug 15, 2014

9. Rutstein SORG. Guide to DHS statistics. 2006

10. Population division world contraceptive Use. UnitedNations://www.un.org/ esa/population/ publications, 2009. accessed November 072015

11. Casterline sekbajb. Understanding Unmet Need: History, Theory, and Measurement. The Population Council, Inc. 2014; 45(2): 123-50 
12. Mwaikambo, L., Speizer, I.S., Schurmann, A., Morgan, G., Fikree, F., What works in family planning interventions: a systematic review of the evidence. Studies in Family Planning,2011.42, 67-82.

13. Mbizvo, M.T., Chou, D., Shaw, D., Today's evidence, tomorrow's agenda: implementation of strategies to improve global reproductive health. International Journal of Gynaecology and Obstetrics: 2013, The Official Organ of the International Federation of Gynaecology and Obstetrics 121, S3. http://dx.doi.org/10.1016/j.ijgo.2013.02.007

14. Family Planning and Reproductive Health, 2016. Available at; 〈https://www. usaid.gov/what-wedo/global-health/family-planning .

15. et al., Unmet need for contraception among married women in an urban area of Puducherry, India. The Indian journal of medical research, 2015. 141(1): p. 115.

16. Michael, E.J., Use of contraceptives methods among women in stable marital relations attending health facilities in Kahama district, Shinyanga region, Tanzania, 2012, Muhimbili University of Health and Allied Sciences.

17. United Nations, N.Y., Trends in Contraceptive Use Worldwide: . Department of Economic and Social Affairs, Population Division, 2015(ST/ESA/SER.A/349).

18. Ayanore, M.A., M.P. and, and W. Groot, Unmet reproductive health needs among women in some West African countries: a systematic review of outcome measures and determinants. Reproductive Health, 2016. 13(5).

19. WHO, Contraception. Department of Reproductive Health and Research. 2014.

20. N. Khalil, M. M. Alzahrani , A. F. Siddiqui.; Unmet need and demand for family planning among married women of Abha, Aseer Region in Saudi Arabia; S.N. Khalil et al. / Middle East Fertility Society Journal 23 (2018) 31-36 situhttp://dx.doi.org/10.1016/j.mefs.2017.07.004

21. United Nations Department of Economic and Social Affairs, Population Division. Meeting Demand for Family Planning. Population facts. No. 2013/6 December 2013. Available at http://www.un.org/en/development/desa/

22. Fagbamigbe et al. Demand and Unmet Needs of Contraception Among Sexually Active In-Union Women in Nigeria: Distribution,Associated Characteristics, Barriers, and Program Implications; SAGE OpenJanuary-March 2018: 1-11@ The Author(s) 2018 DOI: 10.1177/2158244017754023 journals.sagepub.com/home/sgo

23. Tanzania Demographic and Health Survey (DHS) 2010 (Dar es Salaam, Tanzania and Calverton, MD: National Bureau of Statistics, Tanzania and ICF Macro, 2011).

24. Central Statistical Agency (CSA) [Ethiopia] and ICF. 2016. Ethiopia Demographic and Health Survey 2016. Addis Ababa, Ethiopia, and Rockville, Maryland, USA: CSA and ICF

25. Ayele, Wondimu, Habtamu Tesfaye, Roman Gebreyes, and Tesfayi Gebreselassie. 2013. Trends and Determinants of Unmet Need for Family Planning and Programme Options, Ethiopia. Further Analysis of the 2000, 2005, and 2011 Demographic and Health Surveys. DHS Further Analysis Reports No. 81.Calverton, Maryland, USA: ICF International 
26. Central Statistical Agency [Ethiopia] and ICF International. Ethiopia Demographic and Health Survey. Addis Ababa, Ethiopia and Calverton, Maryland, USA: Central Statistical Agency and ICF International; 2014

27. Gelawdiwos Gebre et al. Prevalence and factors associated with unmet need for family planning among the currently married reproductive age women in Shire-Enda- Slassie, Northern West of Tigray, Ethiopia 2015: a community based cross-sectional study; available online at: http://www.panafricanmed-journal.com/content/article/23/195/full/

28. Singh S, Darroch JE, Ashford LS ,Addinglt Up: The costs and benefits of investing in sexual and reproductive health, Guttmacher Institute, New York, USA.

29. Unmet need for contraception in developing countries: levels and reasons for not using a method. Guttmacher Institute. 2007

30. Hassan EE, Ghazawy MR, Amein NM (2017) Currently Married Women with an Unmet Need for Contraception in Minia Governorate, Egypt: Profile and Determinants. J Womens Health Reprod Med Vol.1 No.1: 1.

31. Ajong et al. Determinants of unmet need for family planning among women in Urban Cameroon: a cross sectional survey in the Biyem-Assi Health District, Yaoundé Ajong et al. BMC Women's Health (2016) 16:4 DOI 10.1186/s12905-016-0283-9

32. Letamo G,Navaneetham K. Levels, trends and reasons for unmet need for family planning among married women in Botswana: a cross-sectional study. BMJ Open 2015;5:e006603. doi:10.1136/bmjopen-2014-006603

33. Genet et al.; Determinants of unmet need for family planning among currently married women in Dangila town administration, Awi Zone, Amhara regional state;a cross sectional study; Genet et al. Reproductive Health (2015) 12:42 DOI 10.1186/s12978-015-0038-3

34. Chafo K, Doyore F (2014) Unmet Need for Family Planning and Associated Factors among Currently Married Women in Misha District,Southern Ethiopia: A Cross Sectional Study. J Women's Health Care 3: 165. doi:10.4172/2167-0420.1000165

35. Valekar SS, Pandve HT, Chawla PS, Mane AB (2017) Assessment of Unmet Needs of Family Planning and Reasons for Non-Use of Contraceptive Methods among Women in Reproductive Age in Rural Community. J Community Med Health Educ 7: 549. doi: 10.4172/216a1-0711.1000549

36. Tapare VS, Parande MA, Borle PS. Unmet need for contraception among married women of reproductive age in rural Maharashtra. Int J Community Med Public Health 2017;4:3365-71.

37. Mekelle city adminstration and communication bureau: yearly book of Mekelle city administration,2016, pp3; available at: www.mekell/ecity.gov.et e4

38. GURJA, E., Assessment of magnitude and factors associated with unmet need for family planning among married women of reproductive age who are in extended postpartum in Tahtay Koraro Woreda, Tigray regional state, Ethiopia, 2014, AAU.

39. NEGA, M., determinants of unmet need for contraception among currently married couples in west belessa woreda, north gondar of amhara, ethiopia, 2008, aau. 
40. Tessema, A.L., Bishaw, M.A. and Bunare, T.S. (2015) Assessment of the Magnitude and AssociatedFactors of Unmet Need for Family Planning among Women of Reproductive Age Group with Disabilities in Bahir Dar City, Amhara Region, North West Ethiopia. Open Journal of Epidemiology, 5, 51-58. http://dx.doi.org/10.4236/ojepi.2015.51007

41. Valekar SS, Pandve HT, Chawla PS, Mane AB (2017) Assessment of Unmet Needs of Family Planning and Reasons for Non-Use of Contraceptive Methods among Women in Reproductive Age in Rural Community. J Community Med Health Educ 7: 549. doi: 10.4172/216a1-0711.1000549

42. Saoji AJ, et al.: Unmet Need for Contraception: An Assessment for Enriching Public Health Interventions: People's Journal of Scientific Research; January 2017; Volume 10, Issue 1

43. Sapna S.P, Abdul R.K, KA Narayan: unmet needs for contraception in married women in a tribal area of India; Malaysian Journal of Public Health Medicine 2010, Vol.10 (2): 44-51

44. Khan S, Zareen H, Shahzad S. Factors and Determinants of Unmet Needs: Identifying Association Between Variables and Unmet Needs Among Married Women of Child Bearing Age in Lahore, Pakistan. Int Arch BioMed Clin Res. 2018;4(1):165-169.

45. Singh S, Kalhan M, Malik JS, Jangra A, Sharma N, Singh S. Socio-demographic correlates of unmet need for family planning among rural women of Haryana, India. Int J Adv Med 2018;5:624-9.

46. Duressa LT, Getahun A, Regassa T, Babure ZK, Bidu KT (2018) Unmet Need for Family Planning and Related Factors among Currently Married Women in Sibu Sire District, 2016. J Women's Health Care 7: 446. doi:10.4172/2167-0420.1000446

47. Mohammed A, Woldeyohannes D, Feleke A, Megabiaw B (2014) Determinants of modern contraceptive utilization among married women of reproductive age group in North Shoa Zone, Amhara Region, Ethiopia. Reprod Health 11: 1-7.

48. Kandel NR. "Unmet Need for Contraception and its Associated Factors among Married Women of Reproductive Age in Simichaur VDC of Gulmi District”. Health Prospect 2012; 11:11-14.

49. Getiye D.et al. Prevalence and Associated Factors of Unmet need for Family Planning among Married Women in Enemy District, Northwest Ethiopia: A Comparative cross-Sectional Study. Global Journal of Medical research Interdisciplinary. 2013, Vol.13 Issue 4 Version 1.

\section{Figures}




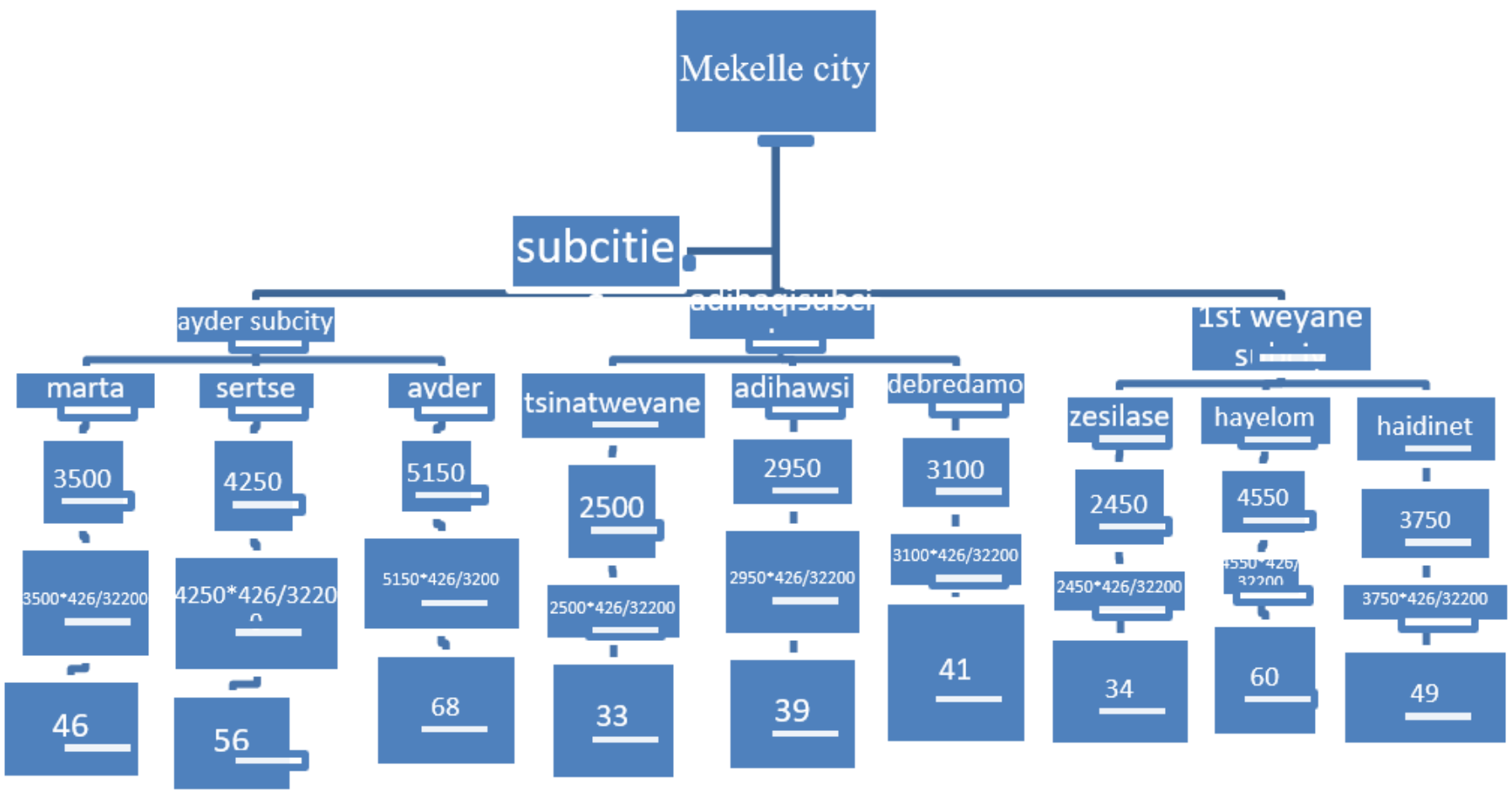

Figure 1

Schematic presentation of sampling procedure for a study on unmet need for modern contraception and associated factors among married women in Mekelle city, Tigray, Northern Ethiopia

\section{Prevalence of Unmet need}

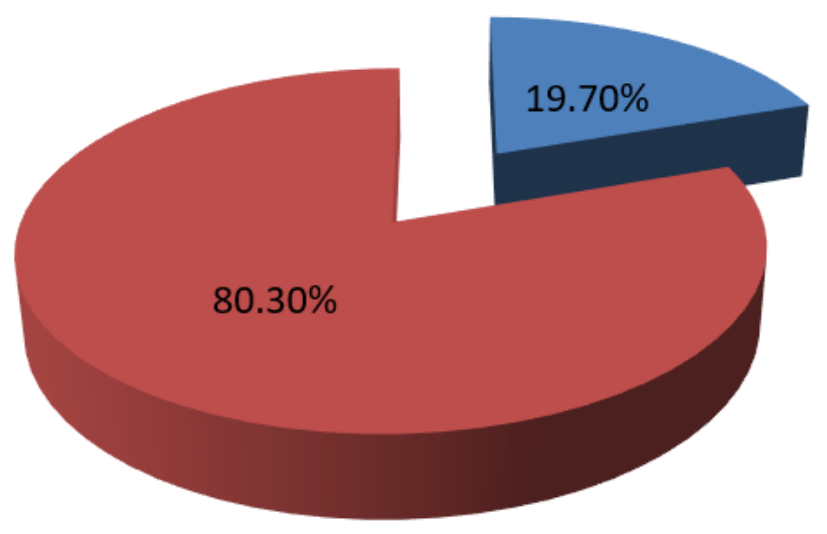

Unmet need

Met need

Figure 2 
Total unmet need for modern contraceptive methods of study participants in Mekelle City, Tigray region, Northern Ethiopia, $2016(n=426)$ 